\title{
The effect of supplementing sow and piglet diets with different forms of iron
}

\section{Aliny Kétilim Novais ${ }^{1}$, Caio Abércio da Silva ${ }^{2}$, Rita de Kássia Silva dos Santos ${ }^{1}$, Cleandro Pazinato Dias ${ }^{1}$, Marco Aurélio Callegari ${ }^{1}$, Eduardo Raele de Oliveira ${ }^{1}$}

\footnotetext{
${ }^{1}$ Universidade Estadual de Londrina, Programa de Pós-graduação em Ciência Animal, Londrina, PR, Brazil.

2 Universidade Estadual de Londrina, Departamento de Zootecnia, Londrina, PR, Brazil.
}

\begin{abstract}
The objective of this study was to evaluate the effect of chelated iron supplementation on gestating and lactating sows and on their suckling and weaned piglets. Reproductive traits, piglet performance, hematological parameters, and the iron concentrations in colostrum, milk, and stillborn livers were measured. Ninety-six sows were subjected to one of three treatment groups. Group T1 comprised pregnant and lactating sows treated with diets supplemented with inorganic iron (551 mg Fe/kg) and suckling piglets administered $200 \mathrm{mg}$ of injectable iron dextran. Group T2 was the same as T1, except that sows after 84 days of gestation, lactating sows, and suckling piglets were fed a diet supplemented with $150 \mathrm{mg}$ Fe/ $\mathrm{kg}$ of chelated iron, and suckling piglets were administered injectable iron dextran. Group T3 was the same as T2 but without injectable iron dextran for suckling piglets. During the nursery phase, all of the weaned piglets were penned with their original groups or treatments and received isonutritive and isocaloric feeds. Piglets from the T2 and T3 groups also received an additional $150 \mathrm{mg} \mathrm{Fe} / \mathrm{kg}$ of chelated iron via their feed. There were no differences among the treatments for reproductive traits or the iron concentrations in the colostrum, milk, or liver. The piglets that did not receive the injectable iron dextran showed the poorest performance during the pre-and post-weaning phases and showed the poorest hematological parameters of the suckling piglets. The chelated iron supplementation is insufficient to meet piglet demand. The iron dextran supply is necessary for suckling and weaned piglets.
\end{abstract}

Key Words: hemoglobin, micro mineral, mineral nutrition, organic mineral, swine

\section{Introduction}

The most commonly used procedure to address physiological iron deficiency is parenteral supplementation with iron dextran in a single dose of $200 \mathrm{mg}$ in the neck, three days after birth (NRC, 2012). However, in this procedure, the weight of the piglets is not taken into consideration when selecting the dose, making it possible to administer an excess of the mineral. Anemia can also occur because of failures in administration (reflux of medication) or because of dosing errors, given that $50 \%$ of the mineral is absorbed by epithelial cells at the injection site (Kolb and Hofmann, 2005). Iron management, although well established, can also have negative consequences including pain at the injection site, which leads to inflammation and feeding inhibition. However, this method is very stressful to the piglets; they will suffer more pain if a greater dosage of iron is given intramuscularly (Chwen et al., 2001). Infections

Received April 12, 2016 and accepted July 21, 2016

Corresponding author: alinyketilim@gmail.com

http://dx.doi.org/10.1590/S1806-92902016001000006

Copyright (c) 2016 Sociedade Brasileira de Zootecnia. This is an Open Access article distributed under the terms of the Creative Commons Attribution License (http://creativecommons.org/licenses/by/4.0/), which permits unrestricted use, distribution, and reproduction in any medium, provided the original work is properly cited. with Streptococcus suis and Escherichia coli can frequently progress to arthritis (Johansen et al., 2004). These pathogens are transferred through the use of contaminated syringes, needles, animal skin, or contaminated hands.

There have been positive results from the use of chelated minerals, unlike from other research, in which the supplements tested did not promote improvement in serum parameters or in the performance of piglets. Wei et al. (2005) treated sows in late pregnancy and during lactation with one of three diets: supplementation with $80 \mathrm{mg}$ of iron sulfate, with $120 \mathrm{mg}$ of chelated iron, or with $120 \mathrm{mg}$ of iron sulfate per $\mathrm{kg}$ of feed. The mineral level in the sow milk treated with $120 \mathrm{mg}$ of chelated iron was higher than in the other treatments. However, the increase in iron concentration was not sufficient to replace the injectable mineral supplementation.

Bertechini et al. (2012) compared the iron content in the blood and liver of piglets and found that the piglets of sows treated with organic minerals had higher mineral levels at the first treatment and a greater weight at birth and at weaning than piglets from sows treated with inorganic minerals. This increase indicates a higher transfer of transplacental iron. Parenteral administration of chelated iron to sows, instead of the traditional treatment of 3-day-old piglets, is not widely practiced on commercial 
farms. Therefore, this study aimed to evaluate the use of dietary chelated iron, classified as a metal proteinate, in the gestation and lactation of sows and in nursing suckling and weaned piglets to determine whether there are similar physiological effects and similar performances obtained when compared to the use of injectable iron dextran.

\section{Material and Methods}

The experiment was approved by the Animal Ethics Committee of the Londrina State University (UEL), registered under number 24.939.2013.09, and was conducted at a commercial swine farm. Ninety-six pregnant Topigs ${ }^{\circledR}$ sows that had been inseminated with male Agroceres PIC ${ }^{\circledR}$ between 0-7 pregnancy cycles and their resulting litters were used until the end of the nursery phase.

The experiment was divided into two phases. The first stage involved the sows and suckling piglets. The randomized experimental design divided the sows into blocks according to their gestational cycle. The sows were selected and distributed into three treatments with thirty-two repetitions, in which each sow and its respective progeny were considered an experimental unit. The gestating sows were housed in individual cages and subjected to treatments for thirty days pre-partum. The lactating sows and their litters were housed in individual pens throughout the lactation period.

The treatments, which were administered by the use of inorganic iron and/or chelated (organic) iron in the rations of sows and in piglets, or by the administration of injectable iron dextran to suckling piglets $(2 \mathrm{~mL}$ via intramuscular, at three days old, corresponding to $200 \mathrm{mg}$ of iron), are outlined as follows. Treatment 1 (T1): pregnant and lactating sows were fed diets with iron sulfate $(551 \mathrm{mg} \mathrm{Fe} / \mathrm{kg}$ and $537 \mathrm{mg}$ $\mathrm{Fe} / \mathrm{kg}$ of feed, respectively) and suckling piglets were administered $200 \mathrm{mg}$ of iron dextran by injection. Treatment 2 (T2): the same as T1, plus $150 \mathrm{mg}$ of chelated iron $/ \mathrm{kg}$ of feed for sows after 84 days of gestation as well as for nursing piglets. Treatment 3 (T3): pregnant and lactating sows were fed diets with iron sulfate $(551 \mathrm{mg} \mathrm{Fe} / \mathrm{kg}$ and $537 \mathrm{mg} \mathrm{Fe} / \mathrm{kg}$ of feed, respectively), plus $150 \mathrm{mg}$ of chelated iron $/ \mathrm{kg}$ of feed for sows after 84 days of gestation as well as for nursing piglets, but without the administration of injectable iron dextran to the suckling piglets.

The iron amino acid chelate was classified as a product of iron salts chelated by amino acids and partially hydrolyzed soluble proteins. The mineral was administered to sows and piglets through the feed at the dose of $150 \mathrm{mg}$ chelated iron $/ \mathrm{kg}$ of feed.
Gestating sows in the second or more reproductive cycles were subjected to restricted feeding, with approximately $3 \mathrm{~kg} /$ day in a single dose. The nulliparous also received $3 \mathrm{~kg}$ feed/day, but in two doses. Lactating sows were fed ad libitum after the third day post-partum, with two tracts/day. The water supply was ad libitum in all phases. All of the piglets were provided with pre-starter diets after 8 days-old until weaning. The feeds during gestation phases, lactation, and nursing feeds were isonutritive and isocaloric, except for the level of iron, which varied according to the treatments (Tables 1 and 2).

The phases of gestation and lactation were evaluated by the number of total births, total live births, the average weight at birth, and weight at weaning at 21 days-old. The incidence of diarrhea in piglets was verified according to the methodology proposed by Rivera et al. (1978).

Samples of colostrum were collected $(50 \mathrm{~mL})$ from all of the functional teats between 4 and $8 \mathrm{~h}$ after delivery and milk samples were collected on the 17th day of lactation. The samples were stored at $4{ }^{\circ} \mathrm{C}$ for the later assessment of iron concentration.

Table 1 - Composition and nutritional value of basal diets used in the pregnancy and lactation phases of sows

\begin{tabular}{|c|c|c|}
\hline & Pregnancy & Lactation \\
\hline \multicolumn{3}{|l|}{ Ingredient } \\
\hline Corn (\%) & 50 & 68 \\
\hline Wheat bran (\%) & 33 & - \\
\hline Soybean meal $(\%)$ & 13 & 28 \\
\hline Pregnancy $^{1}$ lactation $^{2}$ premix $(\%)$ & 4 & 4 \\
\hline \multicolumn{3}{|l|}{ Nutritional and energy values } \\
\hline Metabolizable energy (kcal/kg) & 2,886 & 3,300 \\
\hline Crude protein $(\%)$ & 15.178 & 18.386 \\
\hline Crude fiber $(\%)$ & 4.813 & 3.181 \\
\hline Calcium (\%) & 0.995 & 0.979 \\
\hline Phosphorus (\%) & 0.595 & 0.519 \\
\hline Digestible lysine (\%) & 0.574 & 0.847 \\
\hline Digestible met + cysteine $(\%)$ & 0.423 & 0.512 \\
\hline Digestible threonine $(\%)$ & 0.395 & 0.542 \\
\hline Digestible tryptophan (\%) & 0.151 & 0.189 \\
\hline Sodium $(\%)$ & 0.223 & 0.226 \\
\hline Iron $(\mathrm{mg} / \mathrm{kg})$ & 551 & 537 \\
\hline Manganese (mg/kg) & 73 & 39 \\
\hline Zinc $(\mathrm{mg} / \mathrm{kg})$ & 100 & 74 \\
\hline Copper (mg/kg) & 111 & 16 \\
\hline Iodine $(\mathrm{mg} / \mathrm{kg})$ & 1 & 1 \\
\hline Selenium (mg/kg) & 0.3 & 0.3 \\
\hline
\end{tabular}

${ }^{1}$ Composition per kilogram of product: $170 \mathrm{~g}$ calcium; $17 \mathrm{~g}$ phosphorus; $112,500 \mathrm{IU}$ vitamin A; 20,000 IU vitamin D3; 500 IU vitamin E; $25 \mathrm{mg}$ vitamin $\mathrm{K} 3 ; 25 \mathrm{mg}$ vitamin $\mathrm{B} 1 ; 87.5 \mathrm{mg}$ vitamin $\mathrm{B} 2 ; 31 \mathrm{mg}$ vitamin $\mathrm{B} 6 ; 400 \mathrm{mcg}$ vitamin $\mathrm{B} 12 ; 450 \mathrm{mg}$ niacin; $250 \mathrm{mg}$ pantothenic acid; $30 \mathrm{mg}$ folic acid; $2.25 \mathrm{mg}$ biotin; $8,170 \mathrm{mg}$ choline; $50 \mathrm{~g}$ sodium; $625 \mathrm{mg}$ manganese; $1,375 \mathrm{mg}$ zinc; $1.000 \mathrm{mg}$ iron; 1,875 mg copper; $23 \mathrm{mg}$ iodine; $7.5 \mathrm{mg}$ selenium.

${ }^{2}$ Composition per kilogram of product: $210 \mathrm{~g}$ calcium; $42.50 \mathrm{~g}$ phosphorus; $112,500 \mathrm{IU}$ vitamin A; 20,000 IU vitamin D3; $500 \mathrm{IU}$ vitamin E; $25 \mathrm{mg}$ vitamin $\mathrm{K} 3 ; 25 \mathrm{mg}$ vitamin $\mathrm{B} 1 ; 87 \mathrm{mg}$ vitamin $\mathrm{B} 2 ; 31 \mathrm{mg}$ vitamin $\mathrm{B} 6 ; 400 \mathrm{mcg}$ vitamin $\mathrm{B} 12 ; 450 \mathrm{mg}$ niacin; $250 \mathrm{mg}$ pantothenic acid; $30 \mathrm{mg}$ folic acid; $2.50 \mathrm{mg}$ biotin; $5,000 \mathrm{mg}$ choline; $51 \mathrm{~g}$ sodium; $625 \mathrm{mg}$ manganese; $1,375 \mathrm{mg}$ zinc; $1,000 \mathrm{mg}$ iron; $175 \mathrm{mg}$ copper; $23 \mathrm{mg}$ iodine; $7.5 \mathrm{mg}$ selenium. 
To the evaluation of the iron concentration in the liver, just the stillborn piglets were collected. They were initially weighed, their livers were removed and also weighed.

We analyzed 10 liver samples from each treatment, producing a total of 30 samples.

The iron concentration in the colostrum, milk, and liver were carried out by optical emission spectrometry using inductively coupled plasma (ICP/OES).

On the 8th day, 48 piglets were randomly chosen and $5 \mathrm{~mL}$ samples of blood were collected in an EDTA anticoagulant Vacutainer bottle by puncturing the neck region of the vessel. This produced 16 samples per treatment. At 21 days of age, 57 samples of blood were collected, corresponding to 19 samples per treatment. To obtain hematologic variables, an electronic counter model

Table 2 - Composition and nutritional value of basal diets used for piglets in the suckling and nursery phases

\begin{tabular}{lccc}
\hline & \multicolumn{3}{c}{ Feed } \\
\cline { 2 - 4 } & Pre-starter I & Pre-starter II & Starter I \\
\hline Ingredient & & & \\
Corn (\%) & 40.00 & 35.50 & 52.20 \\
Soybean meal (\%) & - & 17.50 & 23.80 \\
Sugar (\%) & - & 5.00 & 4.00 \\
Supplement 601\%) & 60.00 & - & - \\
Supplement 420 (\%) & - & 42.00 & - \\
Supplement 2003 (\%) & - & - & 20.00 \\
Nutritional and energy values & & & \\
Metabolizable energy (kcal/kg) & 3,400 & 3,400 & 3,400 \\
Crude protein (\%) & 19.200 & 21.400 & 19.500 \\
Crude fiber (\%) & 2.190 & 3.300 & 3.150 \\
Calcium (\%) & 0.480 & 0.380 & 0.590 \\
Phosphorus (\%) & 0.660 & 0.530 & 0.690 \\
Digestible lysine (\%) & 1.22 & 1.25 & 1.06 \\
Digestible met + cysteine (\%) & 0.85 & 0.72 & 0.62 \\
Digestible threonine (\%) & 0.92 & 0.74 & 0.58 \\
Digestible tryptophan (\%) & 0.27 & 0.21 & 0.18 \\
Iron (mg/kg) & 39.42 & 59.54 & 33.75 \\
\hline
\end{tabular}

${ }^{1}$ Composition per kilogram of nursery diet: 218 g crude protein; 60 g ether extract; $22 \mathrm{~g}$ crude fiber; $97 \mathrm{~g}$ mineral matter; $15 \mathrm{~g}$ calcium $(\max ) ; 9.50 \mathrm{mg}$ calcium $(\mathrm{min})$; $8,550 \mathrm{mg}$ phosphorus; $7,000 \mathrm{mg}$ methionine; $20 \mathrm{~g}$ lysine; $14.40 \mathrm{~g}$ threonine; $4,320 \mathrm{mg}$ tryptophan; 33,375 IU vitamin A; 8,775 IU vitamin D3; 229.50 IU vitamin E; $8.77 \mathrm{mg}$ vitamin $\mathrm{K} 3 ; 12.15 \mathrm{mg}$ vitamin $\mathrm{B} 2 ; 6.75 \mathrm{mg}$ vitamin B6; $77.62 \mathrm{mcg} \mathrm{B} 12 ; 57.37 \mathrm{mg}$ niacin; $30.37 \mathrm{mg}$ pantothenic acid; $5.40 \mathrm{mg}$ folic acid; $0.37 \mathrm{mg}$ biotin; $1,080.00 \mathrm{mg}$ choline; $6,000 \mathrm{mg}$ sodium; $144 \mathrm{mg}$ manganese; 4,500 mg zinc; $67.50 \mathrm{mg}$ iron; 14.40 $\mathrm{mg}$ copper; $3.06 \mathrm{mg}$ iodine; $1.08 \mathrm{mg}$ selenium.

${ }^{2}$ Composition per kilogram of nursery diet: $218 \mathrm{~g}$ crude protein; $50 \mathrm{~g}$ ether extract; 212.22 lactose g; $21 \mathrm{~g}$ crude fiber; $99.99 \mathrm{~g}$ mineral matter; $18.72 \mathrm{mg}$ copper; $15.5 \mathrm{~g}$ calcium (max); $12 \mathrm{~g}$ calcium (min); 8,000 mg phosphorus; 6,600 mg methionine; 17.10 g lysine; 10.89 g threonine; 43,200 IU vitamin A; 11,232 IU vitamin D3; $210.78 \mathrm{IU}$ vitamin $\mathrm{E} ; 11.23 \mathrm{mg}$ vitamin $\mathrm{K} 3 ; 15.55 \mathrm{mg}$ vitamin $\mathrm{B} 2 ; 8.64 \mathrm{mg}$ vitamin B6; $99.36 \mathrm{mcg}$ vitamin B12; $73.44 \mathrm{mg}$ niacin; $38.88 \mathrm{mg}$ pantothenic acid; $6.91 \mathrm{mg}$ folic acid; $0.47 \mathrm{mg}$ biotin; $1,544.40 \mathrm{mg}$ choline; $7,500 \mathrm{mg}$ sodium; $187.20 \mathrm{mg}$ manganese; $7,400 \mathrm{mg}$ zinc; $141.75 \mathrm{mg}$ iron; $3.97 \mathrm{mg}$ iodine; $1.38 \mathrm{mg}$ selenium; 1,000 units phytase; $95.24 \mathrm{mg}$ colistin.

${ }^{3}$ Composition per kilogram of nursery diet: 209.43 g crude protein; 45.99 g ether extract; 210.06 g lactose; 33 g crude fiber; $145.53 \mathrm{~g}$ mineral matter; $711 \mathrm{mg}$ copper; $28.20 \mathrm{~g}$ calcium $(\max ) ; 23 \mathrm{~g}$ calcium (min); $14.20 \mathrm{mg}$ phosphorus; $7,560 \mathrm{mg}$ methionine; $19.53 \mathrm{~g}$ lysine; $13.50 \mathrm{~g}$ thiamine; 90,000 IU vitamin A; 23,400 IU vitamin D3; $216.00 \mathrm{IU}$ vitamin E; $23.40 \mathrm{mg}$ vitamin $\mathrm{K} 3 ; 32.40 \mathrm{mg}$ vitamin $\mathrm{B} 2 ; 18.00 \mathrm{mg}$ vitamin $\mathrm{B} 6 ; 207.00 \mathrm{mcg}$ vitamin $\mathrm{B} 12 ; 153 \mathrm{mg}$ niacin; $81.00 \mathrm{mg}$ pantothenic acid; $14.40 \mathrm{mg}$ folic acid; $0.99 \mathrm{mg}$ biotin; $2,700.40 \mathrm{mg}$ choline; $10.80 \mathrm{~g}$ sodium; $36.00 \mathrm{mg}$ manganese; $11.25 \mathrm{~g}$ zinc; $168.75 \mathrm{mg}$ iron; $7.65 \mathrm{mg}$ iodine; $2.28 \mathrm{mg}$ selenium; 2,250 units phytase; $300 \mathrm{mg}$ halquinol.
CC530-Celm ${ }^{\circledR}$ was used. Blood count was assessed by the total number of red blood cells $/ \mu \mathrm{L}$, the hemoglobin concentration $(\mathrm{g} / \mathrm{dL})$, the packed cell volume $(\%)$, the mean corpuscular volume (fL), the mean corpuscular hemoglobin concentration (\%), and the total count of differentiated leukocytes and platelets.

The second phase of the experiment was performed after weaning. Piglets from the first experimental treatments (involving pregnant and lactating sows and their litters), consisting of 1,015 animals were used. Piglets were kept in the same groups and housed in collective boxes (with both genders per pen), with up to 35 animals of both sexes. Piglets were assessed for performance between 24 and 63 days-old. The three treatments were assigned by a completely randomized design, with an unbalanced number of repetitions $(10,10,9)$, and corresponded to the following: $\mathrm{T} 1$ - diets with inorganic iron in the pre-starter I, pre-starter II, and initial I rations (with $39.42,59.54$, and $33.75 \mathrm{mg}$ $\mathrm{Fe} / \mathrm{kg}$ diet, respectively); T2 - equal to T1, plus $150 \mathrm{mg}$ of chelated iron $/ \mathrm{kg}$ diet; $\mathrm{T} 3$ - equal to $\mathrm{T} 2$, but the piglets in the farrowing did not receive the injectable iron dextran. The experimental diets were subdivided into phases to meet the animal requirements (pre-starter I, 21 to 24 days; pre-starter II, 25 to 35 days; initial I, 36-63 days old) and presented isonutritive and isocaloric levels except for the level of chelated iron (Table 2).

The piglets received water and feed ad libitum. The pens had a slatted floor, a semi-automatic feeder, a nipple drinker, and side curtains for thermal control of the environment.

For data analysis, the results of both experiments were submitted to ANOVA and Tukey's test at a 5\% confidence interval. The nonparametric data were subjected to the Kruskal-Wallis test. For the analysis, the statistical software Minitab was used.

\section{Results}

The treatments had no influence on the reproductive parameters (Table 3). The different iron supplementation procedures performed via the feed for pregnant and lactating sows were not sufficient to alter bodily mineral levels, suggesting that neither the colostrum nor the milk had an improvement in iron content (Table 4).

The average iron values in the liver ranged from $163.4 \mathrm{mg} / \mathrm{kg}$ to $185.8 \mathrm{mg} / \mathrm{kg}$. There were no apparent differences among the treatments in terms of the mineral concentrations in the liver, the total iron in the liver, and the relationship between total iron in the liver or in the stillborn body weight (Table 5). 
The treatments with dietary inorganic iron for sows and injectable iron dextran for piglets, with dietary inorganic and chelated iron for sows and injectable iron dextran supplementation with dietary chelated iron for piglets showed high levels of erythrocytes, hemoglobin, and hematocrit at both 8 and 21 days of age (Table 6). There was a loss during the same periods when the injectable iron dextran was withdrawn, resulting in hematological parameters below the normal range for the species, reflecting anemia.

Suckling piglets had mortality rates of $15.7,15.27$, and $14.95 \%$ for treatments with dietary inorganic iron for sows and injectable iron dextran for piglets (T1); with dietary inorganic and chelated iron for sows and injectable iron dextran supplementation with dietary chelated iron piglets (T2); and dietary inorganic and chelated iron for sows and piglets (T3), respectively. No differences were observed $(\mathrm{P}>0.05)$ between the groups, although animals treated with dietary chelated iron (T3) exhibited signs of clinical anemia. Crushing was the main cause of mortality of suckling piglets. The occurrence of diarrhea was insignificant $(1.10,2.03$, and $2.10 \%$ for treatments with injectable iron, injectable iron/chelated and chelated, respectively). The performance results during the nursery phase (Table 7) show differences among the treatments $(\mathrm{P}<0.05)$. The piglets that received injectable iron with or without chelated iron supplementation (T1 and T2) performed better than animals that did not receive injectable iron (T3), indicating that the deprivation of the mineral in the initial phase has repercussions in the subsequent phases.

\section{Discussion}

There was no difference in the birth and weaning weights, but at weaning the piglets that had received injectable iron (T1) and those that had received chelated

Table 3 - Rearing indices of suckling piglets treated with different iron supplementation programs

\begin{tabular}{|c|c|c|c|c|c|}
\hline \multirow{2}{*}{ Parameter } & \multicolumn{3}{|c|}{ Treatment } & \multirow{2}{*}{$\mathrm{CV}(\%)$} & \multirow{2}{*}{ P-value } \\
\hline & $\mathrm{T} 1^{1}$ & $\mathrm{~T} 2^{2}$ & $\mathrm{~T} 3^{3}$ & & \\
\hline Total number of born piglets & $13.32 \pm 2.91$ & $13.87 \pm 2.68$ & $14.38 \pm 2.87$ & 21.30 & 0.862 \\
\hline Number of live births & $12.51 \pm 2.62$ & $12.67 \pm 2.59$ & $12.50 \pm 2.92$ & 21.60 & 0.953 \\
\hline Average birth weight $(\mathrm{kg})$ & $1.357 \pm 0.34$ & $1.384 \pm 0.29$ & $1.391 \pm 0.34$ & 16.13 & 0.980 \\
\hline Daily weight gain $(\mathrm{kg})$ & $0.212 \pm 0.03 \mathrm{a}$ & $0.220 \pm 0.04 \mathrm{a}$ & $0.183 \pm 0.04 b$ & 19.71 & 0.001 \\
\hline Average weight at weaning $(\mathrm{kg})$ & $5.915 \pm 0.62 \mathrm{a}$ & $6.178 \pm 0.92 \mathrm{a}$ & $5.235 \pm 0.85 b$ & 15.69 & 0.001 \\
\hline Number of weaned piglets & $10.92 \pm 2.05$ & $11.10 \pm 1.44$ & $11.05 \pm 1.95$ & 16.53 & 0.979 \\
\hline
\end{tabular}

${ }^{1}$ Inorganic iron and injectable iron dextran supplementation for piglets.

${ }^{2}$ Inorganic iron and dietary chelated iron for sows and injectable iron dextran supplementation for piglets and dietary chelated iron for piglets.

${ }^{3}$ Dietary inorganic and chelated iron for sows and piglets.

$\mathrm{CV}$ - coefficient of variation.

a, b - different letters indicate a significantly different mean.

Table 4 - Iron level in colostrum and milk on the 17th day of lactation in sows fed dietary inorganic and/or chelated iron

\begin{tabular}{|c|c|c|c|c|c|}
\hline \multirow{2}{*}{ Parameter } & \multicolumn{3}{|c|}{ Treatment } & \multirow{2}{*}{$\mathrm{CV}(\%)$} & \multirow{2}{*}{ P-value } \\
\hline & $\mathrm{T} 1^{1}$ & $\mathrm{~T} 2^{2}$ & $\mathrm{~T} 3^{3}$ & & \\
\hline Colostrum Fe (mg/mL) & $1.623 \pm 0.533$ & $1.396 \pm 0.392$ & $1.598 \pm 0.833$ & 39.70 & 0.646 \\
\hline Milk Fe (mg/mL) & $1.193 \pm 0.103$ & $1.262 \pm 0.176$ & $1.334 \pm 0.185$ & 12.23 & 0.278 \\
\hline
\end{tabular}

${ }^{1}$ Inorganic iron and injectable iron dextran supplementation for piglets.

${ }^{2}$ Dietary inorganic and chelated iron for sows and injectable iron dextran supplementation and dietary chelated iron for piglets.

${ }^{3}$ Dietary inorganic and chelated iron for sows and piglets.

$\mathrm{CV}$ - coefficient of variation.

Table 5 - Measurements and iron content in liver of stillborn piglets according to experimental treatment

\begin{tabular}{|c|c|c|c|c|c|}
\hline \multirow{2}{*}{ Parameter } & \multicolumn{3}{|c|}{ Treatment } & \multirow{2}{*}{$\mathrm{CV}(\%)$} & \multirow{2}{*}{ P-value } \\
\hline & $\mathrm{T} 1^{1}$ & $\mathrm{~T} 2^{2}$ & $\mathrm{~T} 3^{3}$ & & \\
\hline Stillborn weight (kg) & $1.055 \pm 0.35$ & $1.341 \pm 0.26$ & $1.251 \pm 0.42$ & 18.56 & 0.138 \\
\hline Liver weight $(\mathrm{g})$ & $37.6 \pm 15.74$ & $49.55 \pm 14.13$ & $40.70 \pm 14.28$ & 15.69 & 0.171 \\
\hline $\mathrm{Fe}$ in liver $(\mathrm{mg} / \mathrm{kg})$ & $185.8 \pm 50.3$ & $171.6 \pm 84.5$ & $163.4 \pm 68.0$ & 39.13 & 0.769 \\
\hline Fe/liver (mg/g) & $6.99 \pm 0.03$ & $8.36 \pm 0.04$ & $6.34 \pm 0.04$ & 49.79 & 0.437 \\
\hline $\mathrm{Fe} /$ body weight (mg/kg) & $6.42 \pm 1.77$ & $6.03 \pm 2.41$ & $5.50 \pm 2.97$ & 39.82 & 0.700 \\
\hline
\end{tabular}

\footnotetext{
${ }^{1}$ Inorganic iron and injectable iron dextran supplementation for piglets.
}

${ }^{2}$ Inorganic iron and chelated iron in feed for sows and injectable iron dextran supplementation and chelated iron via feed for piglets.

${ }^{3}$ Inorganic iron and chelated iron in feed for sows and piglets.

$\mathrm{CV}$ - coefficient of variation. 
Table 6 - Hematological blood indices on the 8th and 21st days of age in piglets subjected to different iron supplementation regimens

\begin{tabular}{|c|c|c|c|c|c|}
\hline \multirow{2}{*}{ Parameter } & \multicolumn{3}{|c|}{ Treatment } & \multirow{2}{*}{$\mathrm{CV}(\%)$} & \multirow{2}{*}{ P-value } \\
\hline & $\mathrm{T} 1^{1}$ & $\mathrm{~T} 2^{2}$ & $\mathrm{~T} 3^{3}$ & & \\
\hline \multicolumn{6}{|c|}{ Values for the 8-day-old } \\
\hline Erythrocytes (millions $/ \mu \mathrm{L}$ ) & $4.697 \pm 0.58 \mathrm{a}$ & $4.489 \pm 0.89 \mathrm{a}$ & $3.474 \pm 0.63 \mathrm{~b}$ & 20.34 & 0.000 \\
\hline Hemoglobin $(\mathrm{g} / \mathrm{dL})$ & $9.600 \pm 1.06 \mathrm{a}$ & $8.836 \pm 1.36 \mathrm{a}$ & $6.555 \pm 1.20 \mathrm{~b}$ & 20.4 & 0.000 \\
\hline Hematocrit $(\%)$ & $34.64 \pm 3.56 \mathrm{a}$ & $31.57 \pm 5.15 \mathrm{a}$ & $23.18 \pm 4.17 \mathrm{~b}$ & 20.51 & 0.000 \\
\hline $\mathrm{MCV}(\mathrm{fL})$ & $73.75 \pm 5.16 \mathrm{a}$ & $70.79 \pm 4.90 \mathrm{ab}$ & $66.94 \pm 4.51 \mathrm{~b}$ & 7.77 & 0.006 \\
\hline $\mathrm{MCHC}(\%)$ & $27.79 \pm 0.72$ & $28.11 \pm 0.90$ & $28.37 \pm 1.21$ & 3.38 & 0.316 \\
\hline Platelets $(\mathrm{n} / \mu \mathrm{L})$ & $467.143 \pm 100 \mathrm{a}$ & $706.643 \pm 244 \mathrm{ab}$ & $1.031 .364 \pm 360 \mathrm{~b}$ & 81.68 & 0.051 \\
\hline Leukocytes $(\mathrm{n} / \mu \mathrm{L})$ & $11176 \pm 3382 \mathrm{a}$ & $12378 \pm 2078 \mathrm{ab}$ & $8659 \pm 2179 b$ & 27.42 & 0.005 \\
\hline S. neutrophils $(\mu \mathrm{L})$ & $6.195 \pm 2947$ & $6.014 \pm 1560$ & $4.513 \pm 2244$ & 41.84 & 0.169 \\
\hline Lymphocytes $(\mu \mathrm{L})$ & $4.741 \pm 1213 b$ & $6.005 \pm 1466 \mathrm{a}$ & $3.801 \pm 1237 \mathrm{~b}$ & 31.87 & 0.001 \\
\hline Monocytes $(\mu \mathrm{L})$ & $163.0 \pm 185$ & $159.0 \pm 97$ & $126.0 \pm 110$ & 88.77 & 0.982 \\
\hline \multicolumn{6}{|c|}{ Values for the 21 st day of age } \\
\hline Erythrocytes (millions $/ \mu \mathrm{L}$ ) & $5.98 \pm 0.99 \mathrm{a}$ & $5.36 \pm 0.47 \mathrm{a}$ & $3.83 \pm 0.69 b$ & 21.73 & 0.000 \\
\hline Hemoglobin $(\mathrm{g} / \mathrm{dL})$ & $11.45 \pm 1.47 \mathrm{a}$ & $10.26 \pm 0.87 \mathrm{~b}$ & $5.19 \pm 1.19 \mathrm{c}$ & 31.01 & 0.000 \\
\hline Hematocrit (\%) & $37.15 \pm 4.27 \mathrm{a}$ & $32.74 \pm 1.96 \mathrm{~b}$ & $17.92 \pm 4.60 \mathrm{c}$ & 28.88 & 0.000 \\
\hline $\mathrm{MCV}(\mathrm{fL})$ & $62.82 \pm 8.62 \mathrm{a}$ & $61.27 \pm 4.57 \mathrm{a}$ & $46.85 \pm 11.07 \mathrm{~b}$ & 18.24 & 0.000 \\
\hline $\mathrm{MCHC}(\%)$ & $30.98 \pm 2.28 \mathrm{ab}$ & $31.37 \pm 1.33 \mathrm{a}$ & $29.51 \pm 2.31 b$ & 6.71 & 0.033 \\
\hline Platelets $(\mathrm{n} / \mu \mathrm{L})$ & $512.8 \pm 148.3 \mathrm{a}$ & $552.1 \pm 136.9 \mathrm{a}$ & $1.300 \pm 559 \mathrm{~b}$ & 62.36 & 0.000 \\
\hline Leukocytes $(\mathrm{n} / \mu \mathrm{L})$ & $12729 \pm 3382 \mathrm{a}$ & $10358 \pm 2078 \mathrm{a}$ & $9082 \pm 2179 b$ & 33.06 & 0.005 \\
\hline S. neutrophils $(\mu \mathrm{L})$ & $6.178 \pm 2729 a$ & $4.239 \pm 2338 \mathrm{a}$ & $3.247 \pm 2834 \mathrm{~b}$ & 62.25 & 0.010 \\
\hline Lymphocytes $(\mu \mathrm{L})$ & $6.248 \pm 2516$ & $5.864 \pm 1473$ & $5.630 \pm 1889$ & 3222 & 0.724 \\
\hline Monocytes $(\mu \mathrm{L})$ & $153.3 \pm 188.3$ & $83.2 \pm 92.4$ & $69.3 \pm 71.2$ & 125.98 & 0.566 \\
\hline
\end{tabular}

${ }^{1}$ Inorganic iron and injectable iron dextran supplementation for piglets.

${ }^{2}$ Inorganic iron and chelated iron in feed for sows and injectable iron dextran supplementation and chelated iron via feed for piglets.

${ }^{3}$ Inorganic iron and chelated iron in feed for sows and piglets.

$\mathrm{CV}$ - coefficient of variation; $\mathrm{MCV}$ - mean corpuscular volume; $\mathrm{MCHC}$ - mean corpuscular hemoglobin concentration.

a, $\mathrm{b}$ - different letters indicate a significantly different mean.

Table 7 - Rearing indices of weaned piglets subjected to different iron supplementation regimens

\begin{tabular}{|c|c|c|c|c|c|}
\hline \multirow{2}{*}{ Parameter } & \multicolumn{3}{|c|}{ Treatment } & \multirow{2}{*}{$\mathrm{CV}(\%)$} & \multirow{2}{*}{ P-value } \\
\hline & $\mathrm{T} 1^{1}$ & $\mathrm{~T} 2^{2}$ & $\mathrm{~T} 3^{3}$ & & \\
\hline Mean weight at 24 days $(\mathrm{kg})$ & $6.190 \pm 1.40 \mathrm{a}$ & $6.590 \pm 1.81 \mathrm{a}$ & $5.452 \pm 1.46 \mathrm{~b}$ & 25.38 & 0.003 \\
\hline Mean weight at 63 days $(\mathrm{kg})$ & $20.816 \pm 2.51 \mathrm{a}$ & $21.911 \pm 2.92 \mathrm{a}$ & $17.582 \pm 2.73 b$ & 15.85 & 0.007 \\
\hline Daily gain weight (kg) & $0.375 \pm 0.03 \mathrm{a}$ & $0.403 \pm 0.04 \mathrm{a}$ & $0.311 \pm 0.04 \mathrm{~b}$ & 13.70 & 0.001 \\
\hline
\end{tabular}

\footnotetext{
${ }^{1}$ Inorganic iron.

${ }^{2}$ Inorganic iron and chelated iron.

${ }^{3}$ Inorganic iron and chelated iron except iron dextran phase of suckling piglet.

$\mathrm{CV}$ - coefficient of variation.

a, b - different letters indicate a significantly different mean.
}

iron through their feed, in addition to injectable iron dextran (T2), showed better performance than those that did not receive the injectable iron dextran (T3) (Table 3). This demonstrates that the chelated iron did not influence the performance of piglets, but the supply of injectable iron dextran was essential for piglet development.

These results contradict the findings of Svoboda and Drabek (2003), which conclude that free access to a commercial product containing iron chelated with aminoacid vehicles prevents piglet anemia and results in piglet growth comparable to that of piglets that received injectable iron dextran.

Piglets have a high iron demand in the first weeks of life. If this demand is not met, growth will suffer. Peters and Mahan (2008) also tested the effects of treatment with organic minerals on piglet weight at birth and at weaning. The results of their study differed from ours; they found that litters in the group treated with diets containing organic minerals were heavier, with more weight gained before weaning.

Acda and Chae (2002) used organic and inorganic mineral in sow diets in four treatments. Two had a low concentration of organic minerals $(87.5$ and $50 \mathrm{mg}$ $\mathrm{Fe} / \mathrm{kg}$ ) and two had high concentrations of inorganic mineral (100 and $175 \mathrm{mg} \mathrm{Fe} / \mathrm{kg}$ ). They did not observe any difference $(\mathrm{P}>0.05)$ in the birth weight. However, the piglets from sows that received a low level of organic minerals during the lactating period had a tendency to grow faster $(\mathrm{P}<0.10)$, resulting in higher body weight at weaning $(\mathrm{P}<0.05)$. These results also differed from those obtained 
by Close (1999), who evaluated organic iron supplementation (90 $\mathrm{mg} / \mathrm{kg}$ ) compared with the inorganic iron injection (60 and $80 \mathrm{mg} / \mathrm{kg}$ ) in sow diets in the final third of pregnancy and throughout lactation. The author observed that the organic minerals were more effective and resulted in litters with higher iron stores, fewer stillbirths, piglets that were heavier at birth and had higher hemoglobin values, as well as a reduced mortality rate and heavier weight at weaning.

Our results observed for the iron level in colostrum and milk demonstrate that neither the colostrum nor the milk had an improvement in iron content.

These results do not agree with those of Wei et al. (2005), who tested sows that were submitted to one of three diets in late pregnancy and throughout lactation $(80 \mathrm{mg}$ of iron sulfate, $120 \mathrm{mg}$ of chelated iron, and $120 \mathrm{mg} \mathrm{Fe} / \mathrm{kg}$ of iron sulfate). They found a higher iron level in the sow milk for the group that received $120 \mathrm{mg}$ of chelated iron $(\mathrm{P}<0.05)$, suggesting higher absorption and utilization of chelated $\mathrm{Fe}$ and higher transfer into the mammary gland. However, it also could not replace the injectable iron supplements of piglets.

The results of the present study (Table 4) do not support these observations; the chelated iron used in this study does not suggest presenting a better absorption than the inorganic iron used in the gestation and lactation feed controls. Trace minerals have predominantly been used in their inorganic form, so the efficacy of organic minerals in pig nutrition requires further study, especially in the reproductive phase.

According to Bertechini et al. (2012), supplementing pre-partum sows with 40 and $80 \mathrm{mg}$ of chelated iron/ $\mathrm{kg}$ diet raised the levels of serum transferrin and the iron content in colostrum, which was higher than the levels attained after feed supplementation with 40 and $80 \mathrm{mg} / \mathrm{kg}$ of inorganic iron.

Douglas et al. (1972) reported that placental iron transfer in sows that were supplemented with ferric citrate increased the mineral content in fetal tissues (heart, kidney, pancreas, and liver), with the largest increase observed in the liver, which corresponded to $0.533 \%$ of the applied dose. This increased the iron deposition by approximately $1.3 \%$ and is related to the high level of transferrin. There is an increase of iron in fetal tissues in response to iron supplementation for sows, but the increase is limited by the placental transfer.

The present results also contradict the observations of Bertechini et al. (2012), who conclude that piglets from sows supplemented with organic minerals are born with higher levels of iron in the blood and increased iron stores in the liver.
Prolonged deprivation of iron causes performance degradation and the development of anemia, which is evidenced by a sharp drop in the number of red blood cells in circulation (Suttle, 2010).

Complexed and chelated minerals are thought to be more bioavailable and, therefore, more efficiently used by the animal. The results indicate advantages for the supplementation of sows and the effect of sow supplementation on the piglets. However, the supplementation of iron dextran by injection does not help the piglets. The results support the conclusions of Harmon et al. (2000), who concluded that the iron proteinate, a mineral chelated by a protein component, affects piglet survival at birth, but does not alter the hematological parameters of piglets when offered in ration at the end of pregnancy and during lactation.

Differences were observed for the mean corpuscular volume and platelet count in piglets that received injectable iron (T1 and T2), when compared to those that received iron feed supplementation (T3). These differences were determined by either the deprivation of the mineral or by the deprivation of the injectable iron dextran administration. The mean corpuscular volume is a good indicator for anemia after birth. In piglets that did not receive iron, the cells become microcytic and the MCV will decrease (Jain, 1993). The mean corpuscular hemoglobin concentration did not show significant differences among the treatments. According to Wallach and Kanaan (2003), large platelets are common in anemic animals that do not receive injectable iron dextran.

The global leukocyte count showed differences among the treatments, with lower counts in piglets that did not receive injectable iron (T1). Gainer and Guarnieri (1985) report a decrease in white blood cell counts in the bloodstream. Piglet immunocompetence is reduced by early iron deficiency. This effect is especially relevant for cell-mediated immunity and for the phagocytic activity of neutrophils. Svoboda et al. (2004) describe a failure in the mitotic activity of lymphocytes in vitro and the changes in the distribution of lymphocytes in the blood of piglets with iron deficiency. They concluded that iron deficiency negatively affects the immune competence of piglets.

The animals that received only dietary chelated iron without supplemental iron by injection (T1) showed lower hematocrit, hemoglobin, mean corpuscular hemoglobin, and mean corpuscular volume, which are indicators of hypochromic-microcytic anemia. Animals that received injectable iron and the inclusion of dietary organic minerals from the 8th day of life showed higher hematocrit and hemoglobin levels, but levels that were still lower than 
those of the animals that received injectable iron (T1 and T2). Although the results are different for the treatments with dietary inorganic iron for sows and injectable iron dextran for piglets versus the dietary inorganic and chelated iron for sows and injectable iron dextran supplementation and dietary chelated iron for piglets, they do not result in a deficiency or anemia, and both produce blood parameters within the normal limits (Svoboda and Drabek, 2005).

Iron deficiency is associated with a reduced phagocytic capacity in granulocytes. Neutrophils have many ironcontaining compounds as well as myeloperoxidase, an enzyme that contributes to antimicrobial activity (Table 6) (Egeli et al., 1998).

The research results on the relative bioavailability of chelated mineral sources for swine were inconsistent and varied depending on the inorganic mineral source used as standard (its degree of solubility and chemical formula). The results also depended on the organic mineral characteristics, the mineral interaction with other food components, the iron content, and the proportion of other minerals in the diet. The results were also affected by the response criteria considered for estimating the bioavailability, age and physiological state of the animals, and previous degree of mineral restriction imposed on the animals (Wang et al., 2014). The results of this study diverged from others that noted the efficacy of dietary chelated iron in preventing piglet anemia and should be kept in mind, especially when the aspects described above are observed.

\section{Conclusions}

The administration of iron proteinate at a dose of $150 \mathrm{mg} / \mathrm{kg}$ of feed for sows in late gestation and lactation and also via feed for suckling piglets do not produce a significant response compared with the traditional management of iron supplementation by dextran injection in piglets. Supplementation with iron proteinate in piglets in the nursery phase does not improve animal performance.

\section{References}

Acda, S. P. and Chae, B. J. 2002. A review on the applications of organic trace minerals in pig nutrition. Pakistan Journal of Nutrition 1:25-30.

Bertechini, A. G.; Fassani, E. J.; Brito, J. A. G. and Barrios, P. R. 2012. Effects of dietary mineral bioplex in pregnant and lactating sow diets on piglet performance and physiological characteristics. Revista Brasileira de Zootecnia 41:624-629.

Close, W. H. 1999. Mineral nutrition in the new millenium: the scientific case for organic minerals. p.131-142. In: Concept in pig science. Lyons, T. P. and Cole, D. J. A., eds. Nottingham University Press, Nottingham, UK.

Chwen, L. T.; Heng, L. K.; Lee, T. H.; Kong, M. C. and Yoon, C. P. 2001. The effects of iron supplementation in preweaning piglets. Malaysian Journal of Nutrition 7:41-49.

Douglas, T. A.; Rent, J. P.; Watts, C. and Ducker, H. A. 1972. Placental transfer of iron in the sow (Sus domesticus).Compendium Biochemistry Phisiology 43:665-671.

Egeli, A. K.; Framstad, T. and Morberg, H. 1998. Clinical biochemistry, haematology and body weight in piglets. Acta Veterinaria Scandinavica 39:381-393.

Gainer, J. H. and Guarnieri, J. 1985. Effects of poly I:C in porcine iron-deficient neutropenia. Cornell Veterinarian 75:454-465.

Harmon, B. G.; Barlow, S. L. and Einstein, M. E. 2000. Bioplex iron vs iron sulfate in estation/lactation diets fed sows: effects on piglet iron status and mortality. Journal of Animal Science 82:62.

Jain, N. C. 1993. Blood loss or hemorragic anemias. Essentials of veterinary hematology. Lea and Febiger, Philadelphia.

Johansen, M.; Alban, L.; Kjaesgaard, H. D. and Baebo, P. 2004. Factors associated with suckling piglet average daily gain. Preventive Veterinary Medicine 63:91-102.

Kolb, E. and Hofmann, U. 2005. Significance, metabolism and administration of iron compounds to pigs: A review. Tieraerztliche Umschau 60:365-371.

NRC - National Research Council. 2012. Nutrient requirements of swine. 11th ed. National Academic Press, Washington, D.C.

Peters, J. C. and Mahan, D. C. 2008. Effects of dietary organic and inorganic trace mineral levels on sow reproductive performance and daily mineral intake over six parities. Journal Animal Science $86: 2247-2260$

Rivera, E. R.; Armstrong, W. D.; Clawson, A. J. and Linnerud, A. C. 1978. Effect of dietary oats and kaolin on perfornance and incidence of diarrhea of weanling pigs. Journal of Animal Science 46:1685-1693.

Suttle, N. F. 2010. Mineral nutrition of livestock. 4th ed. CABI, Oxfordshire.

Svoboda, M. and Drabek, J. 2003. Efficiency of voluntary consumption of amino acid chelated iron in preventing anaemia of suckling piglets. Acta Veterinarya Brno 72:499-507.

Svoboda, M.; Drabek, J.; Krejci, J.; Rejakova, Z. and Faldyna, M. 2004. Impairment of the peripheral lymphoid compartment in iron-deficient piglets. Journal Veterinary Medicin 51:231-237.

Svoboda, M. and Drabek, J. 2005. Iron deficiency in suckling piglets: etiology, clinical aspects and diagnosis. Folia Veterinary 49:104-111.

Wallach, J. and Kanaan, S. 2003. Interpretation of laboratory tests. Interpretação de exames laboratoriais. Medsi, Rio de Janeiro.

Wang, J.; Li, D.; Che, L.; Lin, Y.; Fang, Z.; Xu, S. and Wu, D. 2014. Influence of organic iron complex on sow reproductive performance and iron status of nursing pigs. Livestock Science 160:89-96

Wei, K. Q.; Xu, Z. R.; Luo, X. G.; Zeng, L. L.; Chen, W. R. and Timothy, M. F. 2005. Effects of iron from an amio acid complex on the iron status of neonatal and suckling piglets. Asian-Australasian Journal of Animal Sciences 18:1485-1491. 